\title{
ECONOMIC VALUE ADDED AS AN INDICATOR OF REGIONAL ECONOMIC GROWTH
}

\author{
Senior lecturer Anna Moskvina,
}

Assoc. Prof. DSc Irina Filimonenko,

Assoc. Prof. Tatiana Likhacheva,

Prof. DSc. Zoya Vasilyeva,

Siberian Federal University, Russia

\begin{abstract}
Not only the economy, but also the whole society's aim at economic growth in terms of qualitative and quantitative improvement of the population's standard of living. At present, when the innovative economic sector, the service industry and knowledge have come to the fore, the concept of economic growth requires rethinking.

Approaches to determining the quality of economic growth can be classified based on the absolute quantitative economic indicators (GDP, GNP, NI, national wealth, etc.), based on the relative quantitative economic indicators (GDP per capita, consumption, savings, etc.), based on the qualitative socio-economic indicators (educational level, health, level of infrastructure development, etc.). However, the implementation of economic growth ideas for strategic planning at the sub-regional level is considered the main indicator of economic performance.
\end{abstract}

Various methods of economic growth evaluation at the sub-regional level are used for economic growth assessment in terms of its quality. This paper proposes "municipal economic value added" (EVAM) as an indicator of economic growth, which can be used for regional strategic planning and generates GRP in the region and on the municipality level.

A large part of EVAM is created by mining and processing industries. In sum, these two form $92.3 \%$ of EVAM. The share of trade, catering and transport makes $2.81 \%$, production and distribution of electricity, gas and water $-2.27 \%$, construction $-1.7 \%$. The smallest share is for agriculture, hunting and forestry, as well as governance, social services, education and health care.

As for the territorial structure of EVAM, most (more than 80\%) is created in Turukhansk, Norilsk, Krasnoyarsk, the North-Yenisei areas, Krasnoyarsk Krai being considered a specific case for the research.

Clustering technique (Ward's method) was used for data processing. The target function acts as intragroup sum of squares of deviations, which is the sum of squares of distances between each point (object) and the average for the cluster containing that object.

The cluster analysis showed that in terms of EVAM, Krasnoyarsk Krai municipalities can be divided into 5 clusters. The highest EVAM value is created in clusters 1 and 2, including Norilsk city, Krasnoyarsk city, Turukhansk and the North-Yenisei areas. Clusters 3, 4 including Taimyr, Bolsheuluyskiy and Motyginsky areas, lag behind the 
leaders, but, at the same time, are far ahead "outsiders" - other areas of the region that represent clusters five and six.

In conclusion, ADSM allows not only assessing economic growth in general, but also characterizing its sources, which in turn, reflect the interests of the stakeholders of municipalities, human capital and wages, business and innovation and investment resources, tax and budget sources of regional development.

Keywords: economic growth, sub-regional level, municipalities, strategic planning, economic value added, EVAM, economic value added of the municipality

\section{INTRODUCTION}

Currently, industry statistics, supplemented by indicators of living standards, labor market conditions and demographic processes is mainly used to make strategic management decisions on the regional and municipal levels of government. However, it does not give generalizing and objective assessment of the results of economic regional development.

At the same time, a growing dependence on the world economy; the transition to a postindustrial and information society with special features; changes in lifestyle and stricter environmental requirements with the transition to the paradigm of sustainable development have ambiguous effect on the economic development of territories and require efficient tools for management of the development.

Analysis of the problem has revealed some gaps in its solution, specifically, the lack of aggregate indicator of economic growth of municipal areas, taking into consideration the peculiarities of the resource development, methodologically based on the System of National Accounts (SNA) and allowing to transform into that of a higher regional level.

However, the experience of this kind is available in different countries and particularly in the EU Member States. Well known Russian scientists present gross municipal product (GMP) as the indicator of cost of the municipality of products produced in the economy, including the production of goods and services, which can have a market and non-market character [2]. Similarly, but including the total production volume of industries in the GMP, conditional municipal product per capita (CMP) and the distribution of gross municipal product (GMP) are calculated respectively [3], [4]. The simplified procedure for calculating the economic value added [5] and the distribution of the gross regional product (GRP) using the production function are presented in a number of recent works on this problem [6].

It seems that to determine GMP the target interested party should be known as well as the purpose. First of all, interested parties can include local and regional authorities, who are place specific territories in relation to each other considering the level of economic activity, investment attractiveness and other purposes. In this regard, GMP is to be considered as a statistic indicator, corresponding to such basic statistical indicators at the regional level as the gross regional product (GRP) and gross value added (GVA) in total to each territory respectively [8].

The conducted analysis has shown that the marked "factor method" and the added value method present the closest values with GRP (GVA), the latter in a slightly different interpretation. It is based on the estimated GVA adjusted to backlog statistics residue. 
The Institute of Business Process Management and economics of SibFU has developed and tested the method of calculating the economic value added for the municipalities (EVAM). It is based on calculation of the value added generated at the level of the subjects of territories-enterprises or organizations.

In this case, the economic value added (EVA) consists of the following items:

$$
\mathrm{EVAM}=\mathrm{PB}+\mathrm{CSF}+\mathrm{DFA}+\mathrm{DBT}+\mathrm{BP},
$$

where PB is payroll budget; CSF is contributions to social funds, accrued payroll budget; DFA is consumption (depreciation) of fixed assets, intangible assets and inventories; DBT is direct and indirect business taxes paid on the value added; BP is balance profit.

The proposed indicator of economic value added of the municipality (EVAM) characterizes the value created by External Economic Activity (EEA), and includes a set of tools on the payroll budget, depreciation and profit. In addition, EVAM expresses the interests of the main stakeholders - business, population and the municipality itself presented by local government.

Therefore EVAM logically fits into the regional planning system, creating opportunities for the strategic management of economic growth and development of the region's territory and creates opportunities to characterize the combined impact of the economic activity of municipalities and their economic growth prospects in the region as a whole.

The stages for the methodological approach implementation to calculation of EVAM and their efficiency are presented in Table 1

Table 1 - Stages of the evaluation and implementation of economic value added of municipalities in the municipalities of the Krasnoyarsk Krai

\begin{tabular}{|c|c|c|}
\hline Stage of research & Indicators / analysis criteria & Result of research \\
\hline \multirow[t]{2}{*}{$\begin{array}{l}1 \text { EVAM assessment of } \\
\text { municipalities and their } \\
\text { clustering in terms of } \\
\text { each element forming the } \\
\text { indicator }\end{array}$} & $\begin{array}{l}\text { 1.1 EVAM dynamics } \\
\text { 1.2 EVAM structure on economic } \\
\text { activities } \\
\text { 1.3 EVAM structure by elemental } \\
\text { composition } \\
\text { 1.4 Dimensional EVAM structure }\end{array}$ & $\begin{array}{l}\text { The growth rate of EVAM } \\
\text { EEA, making the largest contribution } \\
\text { into EVAM } \\
\text { Municipalities, which make the } \\
\text { largest contribution into the EVAM }\end{array}$ \\
\hline & $\begin{array}{l}1.5 \quad \text { Differentiation of } \\
\text { municipalities on EVAM terms of } \\
\text { elemental composition }\end{array}$ & $\begin{array}{l}\text { Territorial clusters in terms of EVAM } \\
\text { and its elemental composition, their } \\
\text { transformation by period under } \\
\text { analysis }\end{array}$ \\
\hline $\begin{array}{l}2 \text { Evaluation of strategic } \\
\text { factors, resource } \\
\text { development areas of } \\
\text { municipalities and } \\
\text { clustering of territories } \\
\text { according to their size }\end{array}$ & $\begin{array}{l}\text { 2.1 The dynamics of the human } \\
\text { development index } \\
2.2 \text { The dynamics of the } \\
\text { innovativeness index of the } \\
\text { business environment } \\
\text { 2.3 The dynamics of the index of } \\
\text { investment activity }\end{array}$ & $\begin{array}{l}\text { Territorial clusters based on the } \\
\text { human development index } \\
\text { Territorial clusters based on the index } \\
\text { of innovativeness of the business } \\
\text { environment } \\
\text { Territorial clusters based on the index } \\
\text { of investment activity }\end{array}$ \\
\hline $\begin{array}{l}3 \text { Establishing the } \\
\text { relationship between } \\
\text { economic growth and } \\
\text { strategic } \\
\text { resources }\end{array}$ & $\begin{array}{l}\text { Equation of connection between } \\
\text { EVAM and indices of human } \\
\text { development, innovative business } \\
\text { environment, investment activity }\end{array}$ & $\begin{array}{l}\text { Equation connection between EVAM } \\
\text { and strategic resources factors, } \\
\text { elasticity factors of economic growth } \\
\text { strategy of territories }\end{array}$ \\
\hline
\end{tabular}




\section{METHODS AND MATERIALS}

IBM SPSS Statistics software was used for data processing and clustering of territories with different levels of EVAM. Clustering of municipalities of the Krasnoyarsk Krai is conducted using Ward's method.

The possibility of economic growth for clusters of territories is calculated based on the construction of the power production functions with a high degree of reliability. Using in combination with the factor analysis can significantly reduce the amount of background information, and more different study the structure of the relationships represented in it variable.

A number of factors were determined using "scree" method. To simplify the interpretation of the results of the factor analysis and rise the quality of the relationships formed "VARIMAX" rotation method was applying, which further adjusted the number of variables and factor loadings, making them more uniform. All this allowed using EVAM indicator for predicting economic growth of the region's territories in the four scenario options: inertial, modernization, and social infrastructure.

\section{RESULTS}

The practical implementation of methodological approach was carried out in all municipalities of the region until 2010, and later, after improving in 2011-2014. The results confirmed its compliance with goals.

So, it was identified, that the highest EVAM values were created in such municipalities as the Turukhansk region (due to development of the Vankor oil field), Norilsk and Krasnoyarsk, the North-Yenisei region (being a gold mining center of Krasnoyarsk Krai) - more than $80 \%$ (Table 2).

As the analyses have revealed, about $10 \%$ EVAM was created by fifty three territories in the region, which cannot be considered satisfactory.

The structure of the economic value added of municipalities of the Krasnoyarsk Krai by types of economic activity shows that most of the EVAM was created by EEA "Mining" and "Manufacturing". In sum, they make 92.3\% of EVAM. The share of trade, catering and transport is amounted to $2.81 \%$, electricity generation and distribution, gas and water is $2.27 \%$, construction is $1.7 \%$ in 2014 . The smallest part of EVAM is in agriculture, hunting and forestry, as well as management, social services, education and health.

The highest level of EVAM is in the first and second clusters, "outsiders" are those clusters five and six, which include most of the region. 


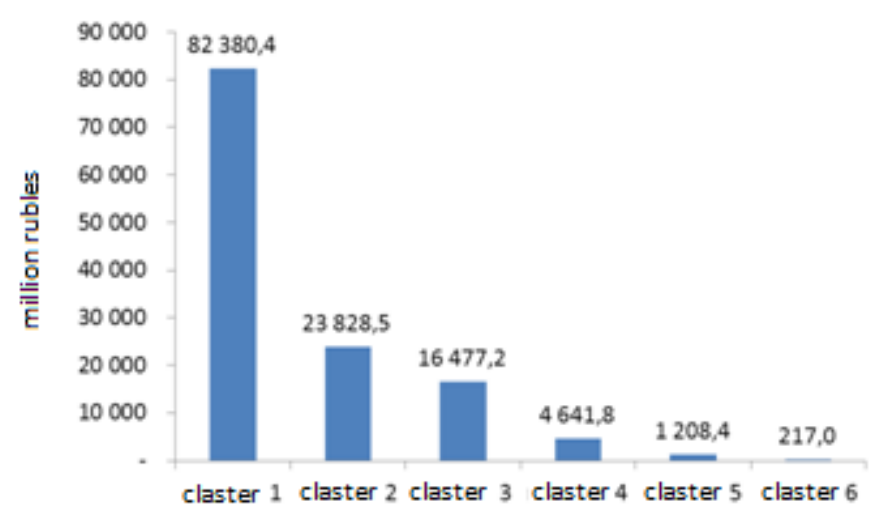

Figure 1 - The average value of EVAM of region municipalities of the Krasnoyarsk Krai in 2014, million rubles

Describing EVAM elemental structure, it should be noted that in general, a large share in the composition of the indicator takes the profit, smaller refers to payroll budget (Figure 2).

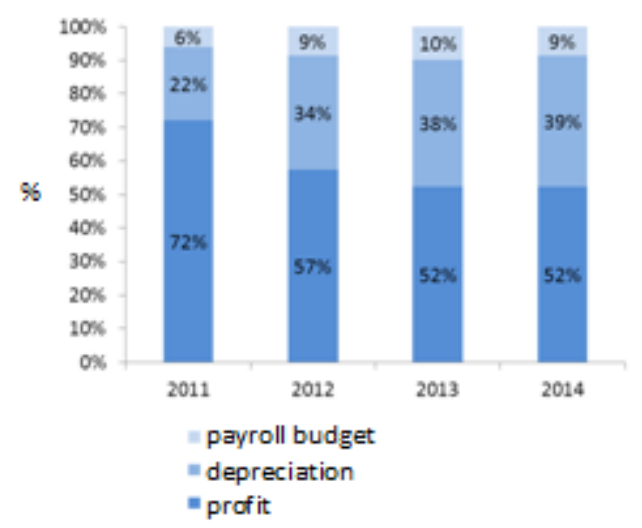

Figure 2 - EVAM Structure of municipalities of the Krasnoyarsk Krai per elements in 2011-2014, \%

Clustering of municipalities in terms of EVAM structure allowed classifying all Krai territories into 7 clusters in 2014 (Table 3, Figure 3).

Table 2 - Average values of EVAM structural elements used for the differentiation of the municipalities of the Krasnoyarsk Krai in 2014, \%

\begin{tabular}{|l|l|l|l|l|l|l|l|}
\hline Density & Cluster 1 & Cluster 2 & Cluster 3 & Cluster 4 & Cluster 5 & Cluster 6 & Cluster 7 \\
\hline $\begin{array}{l}\text { Remuneration } \\
\text { of labor }\end{array}$ & 96.30 & 22.40 & 3.63 & 14.48 & 54.40 & 27.36 & 71.82 \\
\hline Depreciation & 158.01 & 42.33 & 14.50 & 30.48 & 35.21 & 63.39 & 10.69 \\
\hline Profit & -154.31 & 35.27 & 81.87 & 55.04 & 10.39 & 9.25 & 17.49 \\
\hline
\end{tabular}




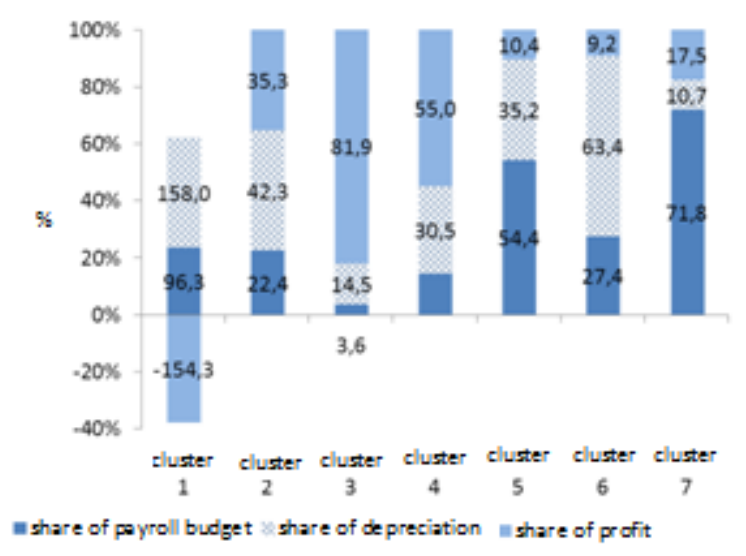

Figure 3 - Structure of the economic value added of municipalities of the Krasnoyarsk Krai in $2014, \%$

The stability of growth rates (with variation coefficient of less than $10 \%$ ) was identified in 8 municipalities. The second group with a moderate oscillation of EVAM (coefficient of variation in the range of $10-30 \%$ ) included most of the region's municipalities is 36 . The third group with considerable variation EVAM (30\% coefficient of variation) includes 15 municipalities.

Conjugacy of growth rates and variability of EVAM (Table 4) have led to the conclusion that the stability is typical for areas with reduced EVAM and for increasing (moderate) areas. Moderate volatility index is more typical for temperate areas; strong fluctuations occur in the territories, showing explosive growth rate EVAM.

Table 3 - Classification of municipalities of the Krasnoyarsk Krai in terms of growth and its stability EVAM for 2011-2014

\begin{tabular}{|c|c|c|c|c|c|}
\hline & GroupI & GroupII & GroupIII & \multirow[b]{2}{*}{ Tota } \\
\hline & & $\begin{array}{c}\text { EDSM } \\
\text { reduction }\end{array}$ & $\begin{array}{l}\text { EDSM growth } \\
\text { of up to } 2 \\
\text { times }\end{array}$ & $\begin{array}{l}\text { EDSM growth } \\
\text { of more than } 2 \\
\text { times }\end{array}$ & \\
\hline Group 1 & stability & 4 & 4 & 0 & 8 \\
\hline Group 2 & moderate volatility & 21 & 14 & 1 & 36 \\
\hline Group 3 & strong volatility & 3 & 3 & 9 & 15 \\
\hline Total & & 28 & 21 & 10 & \\
\hline
\end{tabular}

\section{CONCLUSION}

Cluster analysis of EVAM structure by municipalities leads to the following conclusions: 
1. Identification of a typical cluster indicates the presence of regularities in the EVAM creation.

2. Elements in EVAM structure has mobility resulting in the emergence of new clusters, as well as changes in their boundaries.

3. Only a balanced mix of remuneration, amortization (for the most part) and profit (smaller part) create opportunities for economic growth.

Structural analysis allows identifying the main factors influencing EVAM as a whole and on its separate elements: the relationship of wages and quality of human potential; depreciation and return on the investment activity of the territories and the state of their business environment, determining their appeal to "interested parties". Indicator EVAM expanded the potential opportunities for economic growth and its formation based on a qualitative basis.

Thus, as a result of the study not only the quantitative values of the corresponding method parameters, but also made a number of conclusions on improving the research methodology used to improve the reliability of the information base were received.

EVAM can be used as a generalizing indicator of economic activity of the municipalities of the region. Its total value in spatial analysis characterizes the basic statistics of the region. EVAM can be the basis for the development of the rating of municipal territories and their positioning on the contribution to the formation of the result of the economic activity of the region. EVAM can be used in strategic planning and development of territories of the region, and its structural elements, transformed into factors-resources, characterize the features of their behavior and implementation scenarios.

However, in the process of testing the results of the study revealed a number of weaknesses (risks), in particular, the risk of inappropriate use of the tasks of information-statistical base study and the likelihood of displacement vector estimation of strategic management issues to the real strategic development areas in the direction of methodological approaches.

Among the organizational risks present low motivation of regional and local authorities to improve their position in the rankings of economic growth and the lack of support for their initiatives by business and investors.

Overall EVAM indicator being the basis of the economic activity assessment and management of economic growth can stimulate the quality of strategic management in the region. On the one hand, it is an effective tool for objective assessment and multilateral efforts of all levels of government to improve the business environment, innovation activities and the quality of the human potential of the territories, which are, in turn, growth factors of the past. EVAM indicator can be the basis for the evaluation of municipal areas in other regions. To ensure the sustainability of the validity of the positions in terms of territory EVAM necessary to intensify the activities of all participants in the evaluation mechanism in some areas. The latter include the reduction of methodological risk, motivation of management teams, the involvement of municipalities and all the "stakeholders" in the growth management process.

\section{REFERENCES}


[1] Makarov V. New economic self-organization of municipalities / V. Makarov, M. Glazyrin // The Economist. - 2003. - №4.-56p. (in Russian)

[2] Kolechkov D.V. Gross Municipal Product: Methods of calculation and application / D.V.Kolechkov, Yu.A.Gadzhiev, S.A. Timashev, M.N. Makarova // Statistics Questions. - 2012. - №4. -49p. (in Russian)

[3] Koldomova N.V. Development of indicators of quality of life of the population: the experience of the Novosibirsk region. Proceedings of the seminar on the program "The new model of efficient management of municipal education: quality of life in your hands" / N.V. Koldomova. - Novosibirsk: MFI "Siberian Civic Initiatives Support Center", 2007. (in Russian)

[4] Belyakova G.Ya. Improving the method for calculating summary measure of municipalities [Text] / G.Ya. Belyakova, A.I. Frolova // Regional economy: theory and practice.- 2011. - №33. -pp.42-48. (in Russian)

[5] Chekavinsky A.N. Evaluation of the gross domestic product of the city and the direction of its increase [Text] / A.N. Chekavinsky, E.A. Gutnikova / Problems of development area. - 2012. - №2. - pp.36-44. (in Russian)

[6] Lopatin A.A. Improving the performance of long-term forecast of social and economic development of the region [electronic resource] / A.A. Lopatin, A.M., Nabieev // Economy. Finance. Market.- 2005.-№1. (in Russian)

[7] Polintseva N.I. Formation of the system of municipal statistics / N.I. Polintseva // Statistics Questions. - 2005. - №12.-32p. (in Russian) 